\title{
INCESSANT WORRY OR HAPPINESS IN UKRAINIAN
}

In Happiness And Contemporary Society : Conference Proceedings Volume (Lviv, March, 20-21, 2021). Lviv: SPOLOM, 2021. P. 254-257. https://doi.org/10.31108/7.2021.56

ISBN 978-966-919-697-2

\section{НЕПОЗБУВНА БЕНТЕГА АБО ЩАСТЯ ПО-УКРАЇНСЬКИ}

// Щастя та сучасне суспільство : збірник матеріалів міжнародної наукової конференції (Львів, 20-21 березня 2021 р.). - Львів : СПОЛОМ, 2021. С. 254-257. https://doi.org/10.31108/7.2021.56

ISBN 978-966-919-697-2 


\section{SMORZHEVSKA Oksana \\ Ph D in History, Associate professor of Modern history of Ukraine Taras Shevchenko National University of Kyiv (Kyiv, Ukraine)}

\section{INCESSANT WORRY OR HAPPINESS IN UKRAINIAN}

«Incessant worry» - this phrase-meme actively «walks» on social networks and has already become part of the language of everyday life. It is usually used in a somewhat ironic sense. But at the same time, in my opinion, this irony really contains a deep understanding of «what is happiness in Ukrainian». Cordocentrism is considered one of the characteristic features of the Ukrainian mentality. And also antheism (kinship with the native land) and execution (dominance in the psyche of the «feminine principle», but is not synonymous with femininity). All these features have found their embodiment, among other things, in art. And it is precisely the «Incessant worry» that reflects the cordocentrism of the Ukrainian character, and hence the understanding of happiness in Ukrainian. In pursuit of the material components of our everyday life, we have forgotten that happiness is harmony, it is order within ourselves and the creation of a positive attitude around us. Happiness in Ukrainian is coziness, cute little things that make our life more pleasant, it is pleasure from the work that you do, it is your health and your loved ones. And then this «Incessant worry» of Cossack Mamai, a warrior-wise man, in combination with a reeled doll (motanka), acquire a modern sound in our present. It has gone through difficult centuries, tempered in the whirlwind of complex life's vicissitudes and remains national archetypes, the cores of Ukrainian spiritual culture.

KEY WORDS: «Incessant worry», happiness in Ukrainian, archetype, cordocentrism, reeled doll, Cossack Mamai.

\section{СМОРЖЕВСЬКА Оксана}

кандидатка історичних наук, дочентка

Київський національний університет імені Тараса Шевченка

(Київ, Україна)

\section{НЕПОЗБУВНА БЕНТЕГА АБО ЩАСТЯ ПО-УКРАЇНСЬКИ}

«Непозбувна бентега» - це словосполучення-мем досить активно «гуляє» соціальними мережами та вже стало частиною мови повсякдення. Зазвичай його вживають в дещо іронічному сенсі, але при цьому, на мій погляд, в цій іронії закладене насправді глибоке розуміння «що ж таке щастя по-українськи». Кордоцентризм вважають однією 3 характерних рис українського менталітету. А також антеїзм (спорідненість 3 рідною землею) та екзекутивність (домінування у психіці «жіночого начала», але не $є$ синонімом жіночності). Всі ці риси знайшли своє втілення, поміж іншого, й у мистецтві. I от саме «непозбувна бентега» відображає кордоцентризм українського характеру, а звідси - й розуміння щастя по-українськи. У гонитві за матеріальними складовими нашого повсякдення ми забули чи підзабули, що щастя - це гармонія, це лад всередині себе самого та творення позитивного налаштування навколо себе. Щастя по-українськи - це затишок, милі дрібниці, які роблять наше життя приємнішим, це насолода від роботи, яку виконуєш, це здоров'я твоє та твоїх близьких. I тоді ота «небозбувна бентега» Козака Мамая, воїна-мудреця, у поєднанні з Лялькою- 
мотанкою, набувають сучасного звучання в нашому сьогоденні, переживши лихоліття століть та загартувавшись у вихорі складних життєвих перепетій й залишаються національними архетипами, стрижнями духовної культури українців.

КЛЮЧОВІ СЛОВА: «Непозбувна бентега», щастя по-українськи, архетип, кордоцентризм, лялька-мотанка, козак Мамай.

«Непозбувна бентега» - це словосполучення-мем досить активно «гуляє» соціальними мережами та вже стало частиною мови повсякдення. Зазвичай його вживають в дещо іронічному сенсі, але при цьому, на мій погляд, в цій іронії закладене насправді глибоке розуміння «що ж таке щастя по-українськи». «Непозбувна бентега», як приклад постфольклору (хоча й має свого автора перекладача Олега Короля) - це вже своєрідний архетип української культури, втілений в сучасних цифрових технологіях.

Для нас цікавими $є$ національні архетипи, які, за Мартіном Гайдеггером, відображені у ментальності різних народів [4, с. 39]. Архетип не є чимось усталеним раз і назавжди. Він - розвивається, пристосовується до відповідного історичного періоду, культурних парадигм, стилю, «архетипи виявляють спорідненість між творами, авторами, культурами й епохами» [2, с.3-4]. Українські архетипи символічно відображені у міфології, фольклорі, традиціях та обрядах, прикметах та уявленнях. Вони $є$ узагальненням історико-культурного досвіду наших пращурів та отримують «нове дихання» в творчості сучасних митців.

I от саме «непозбувна бентега» відображає кордоцентризм українського характеру, а звідси - й розуміння щастя по-українськи. Тут доречно згадати поетичні рядки Ігора Павлюка:

«Наше щастя пахло апельсинами:

Склянка рому з небесами синіми

І кохання, й батьківщина, степ...

Друзі ще не скурвилися золотом,

Гострий біль зробив нас всіх сильнішими,

Вільними, як вітер перед сном...

Щастя уже пахне полином...» [8, с. 34].

Кордоцентризм - уявлення про зосередження сутності людини в серці, тобто - в почуттях, інтуїції, емоціях. Кордоцентризм вважають однією 3 характерних рис українського менталітету. А також антеїзм (спорідненість 3 рідною землею) та екзекутивність (домінування у психіці «жіночого начала», але не $\epsilon$ синонімом жіночності). Всі ці риси знайшли своє втілення, поміж іншого, й у мистецтві. Мистецтвознавиця Вікторія Драганчук в одному зі своїх досліджень зосередила увагу на архетипі «Ославленої Мадонни» в творчості українських поетів, письменників, композиторів. Втілений він у символі «кордоцентричної не-долі усієї України». Також авторка акцентує увагу на мистецьких образах України як «безталанної вдови», «покривдженої», наголошуючи, що «очевидно, шлях <...>, має пройти і вся архетипна жінка-Україна, вийшовши зі звивихнутості власної не-долі до сприйняття Божої ласки шлях виправлення архетипу <...>». [3, с. 72]. Вже інший образ Жінки + предметні архетипи, втілений в образотворчому мистецтві Ольги Гайдамаки та Марти Пітчук. У Ольги Гайдамаки вже самі назви картин «Володарка», «Мамин Всесвіт», «Берегиня», «Душа полонини», 〈Купальські ворожіння», «Місячна Корова», «Коловорот», «Щедрий Вечір», «Пряха», «Зоряні намиста», «Дух Поля» привертають нашу увагу до української міфології та стародавніх ритуалів й звичаїв, де Жінка виконувала важливу роль, 
втілювала в собі та своїх діях певний стрижень світобудови. Ольга Гайдамака у своїх жіночих образах втілює не якихось конкретних жінок. Це, швидше, символи, сенси української культури, передані крізь призму мисткині. Ольга Гайдамака знайшла себе у відтворенні українського одягу. У кожному регіоні - свій стрій, свої вишивки та елементи одягу. Почала вона з Чернігівщини, де влітку проводила час в селі у бабусі. Особливості стилю Ольги Гайдамаки - маленькі голови 3 велетенськими головними уборами та рукавами. Так вона прагне передати своє захоплення українськими жіночими головними уборами [1]. Ії̈ перша персональна виставка «Душа України» (2016 p., Київ, Літературно-меморіальний будинок-музей Тараса Шевченка) продемонструвала велич духовного спадку, що ми маємо на сьогодні, і який потребує нашої уваги та піклування. В полотнах передано глибинні сенси, в тому числі - й розуміння щастя як гармонії зі своїм внутрішнім Всесвітом та Всесвітом оточуючим. Наприклад, картина «Місячна корова» насичена глибокою синьо-волошковою кольоровою гамою, де як одне ціле виступають Жінка і Корова. Сама художниця так сказала про цей свій твір: «У картині «Місячна корова» я зобразила життя українки в гармонії із годувальницею родини (коровою), яка в ті часи фактично була частиною кожної сім'ї. Корова - символ продуктивних сил Землі, материнства та добробуту. В давні часи наші предки вірили, що ця тварина уособлювала нічне небо, бо роги іiі нагадували молодий Місяць, а молоко - Чумацький Шлях. Молодиця ж одягнена в борщівський весільний стрій (Тернопільщина). А Борщівська сорочка - унікальне явище нашої культури, для якої характерний чорний колір. Деякі люди кажуть, це шана землі, інші - що так жінки «виливали» тугу за чоловіками. Велику увагу я приділила чарівному головному убору, який викладений із герданів та квітів» [7].

Ще одна талановита й самобутня українська художниця Марта Пітчук зазначила в одному зі своїх інтерв'ю: «Я вважаю, що сучасний український художник, повинен пропагувати українське. В своїх картинах хочу показати те, що наше традиційне може бути сучасним, стильним, іти в ногу з часом, але при цьому підкреслювати нашу глибину і традиції». Серія іiі робіт «Мотанка» присвячена зображенню жінок у традиційних українських строях, переважно гуцульських, але $є$ й інші регіони України. Характерною рисою даної серії полотен є закриті обличчя героїні-мотанки. Хоча насправді кожна мотанка має своє обличчя. Художниця спочатку ретельно промальовує обличчя, очі. А вже потім «закриває» свою героїню мазками-нитками, як у традиційної ляльки-мотанки. Так, на думку мисткині, мотанка набуває свого характеру, отримує свою душу: «У картинах поєдную минуле з сучасним. Мотанка - прадавній український оберіг. Лялька попередніх століть зливається в одне ціле із жінкою з плоті й крові. Така мотанка уже не предмет, а особистість - зі своїми думками й поглядами. Вона - втілення минулого, що ожило. Хотіла втілити ідею, що українки - непокірні, жваві, з характером, непрості. Вони всі трохи мольфарки. У мене є гуцульське коріння. Може, воно так впливає» [5]. Жіночі образи-мотанки Марти Пітчук втілюють стихію вітру, як непокору характеру, жагу до волі. Саме гармонія у єдності зі стихією, яку відчуваєш - і є своєрідним щастям. Так вважає не лише сама художниця, а й їі чоловік, художник Юрій Пітчук. Подружжя Пітчуків $є$ авторами низки муралів, зокрема, у Івано-Франківську. У сквері навколо площі Міцкевича в цьому місті у 2019 р. встановили розвантажувальну підстанцію, яка стала ще й арт-об’єктом. Художники Юрій та Марта Пітчуки оформили підстанцію як мистецький об'єкт, що отримав назву «Енергія стихій». Ці стихії - Земля, Вода, Вогонь та Повітря, - уособлені в образах жінок. Саме ці енергії-стихії пронизують Всесвіт та, за задумкою авторів, співіснують в людині, а саме - в жінці. Як розповів Юрій Пітчук, «< ..> хотілось наштовхнути на думку, що в кожному із нас $є$ енергія 
стихій, і що справжнє щастя - це знайти в собі стихію і вчитись жити в гармонії з нею. Земля дає нам відчуття безпеки і рівноваги, вогонь - бажання рухатись та жагу пізнання, вода розкриває відчуття та емоції, а повітря вчить довіряти, віддавати та отримувати. Всі стихії разом є життєдайною енергією. А електроенергія всередині підстанції $\epsilon$ своєрідним п'ятим елементом - комфортом та розвитком, також необхідним для повноцінного життя». [10]. I справді, в гонитві за матеріальними складовими нашого повсякдення ми забули чи підзабули, що щастя - це гармонія, це лад всередині себе самого та творення позитивного налаштування навколо себе. Саме про таке розуміння щастя по-українськи написала в своєму дослідження Ірина Мацко «Секрети українського щастя або Хюге по-українськи» [6]. Щастя по-українськи - це затишок, милі дрібниці, які роблять наше життя приємнішим, це насолода від роботи, яку виконуєш, це здоров'я твоє та твоїх близьких. I тоді ота «небозбувна бентега» Козака Мамая [9], воїна-мудреця, у поєднанні з Лялькою-мотанкою, набувають сучасного звучання в нашому сьогоденні, переживши лихоліття століть та загартувавшись у вихорі складних життєвих перипетій й залишаються національними архетипами, стрижнями духовної культури українців.

\section{ЛІТЕРАТУРА}

1. Гайдамака Ольга. URL: https://haydamaka.com/

2. Доній Т. Архетипи і топоси постмодерністської поезії України і США. Дис... д-ра філос.: 10.01.05 - порівняльне літературознавство. - К.: КНУ імені Тараса Шевченка, 2018. - 230 с.

3. Драганчук В. Архетип Ославленої Мадонни у музичному дискурсі: кордоцентризм української не-долі // Актуальні проблеми мистецької практики і мистецтвознавчої науки, 2015. - Вип. 7. - С. 65-74.

4. Кримський С. Архетипи / Філософський енциклопедичний словник / Ред. В.І. Шинкарук. - К.: Абрис, 2002. - 751 с.

5. Марта Пітчук - феномен західноукраїнського мистецтва / UkrRain. Український дощ. 17.04.20. URL: https://ukrrain.com/marta_pitchuk_fenomen zahidnoukrainskogo mistectva.html

6. Мацко I. Секрети українського щастя або Хюге по-українськи. - Саміт-Книга. 2019. - 208 c.

7. Осмоловська Г. Душа України. Виставка живопису Олі Гайдамаки, 27.07.2016 / ARTMISTO. Культурне життя Києва. URL: http://artmisto.net/2016/07/27/dushaukrayini-vistavka-zhivopisu-oli-gaydamaki/

8. Павлюк І. Магма. - Львів: Світ, 2005. - 280 с.

9. Пошивайло Т. Козак Мамай як етносимвол українців, 1.11.2010 / Музей Івана Гончара. Національний центр народної культури. URL: https://honchar.org.ua/p/odkrovennya-kozaka-mamaya/

10. Таємниця нової арт-підстанції у середмісті Івано-Франківська розкрита! / Прикарпаття. $\quad$ Обленерго. 21.10.2019. URL: https://www.oe.if.ua/uk/articles/5dada4b9db9c427fbc282b68

11. Украинские стилизованные портреты Анны Диденко и Ольги Гайдамаки Мастер дела, 18.12.2018. URL: https://www.youtube.com/watch?v=GeHZaFg$\underline{\mathrm{iF} 0 \& \text { feature }=e m b \_t i t l e}$ 